\title{
Clinical practice recommendations for the treatment of Alport syndrome: a statement of the Alport Syndrome Research Collaborative
}

\author{
Clifford E. Kashtan • Jie Ding • Martin Gregory • \\ Oliver Gross • Laurence Heidet • \\ Bertrand Knebelmann • Michelle Rheault • \\ Christoph Licht
}

Received: 9 December 2011 / Revised: 29 January 2012 / Accepted: 31 January 2012 /Published online: 30 March 2012

(C) The Author(s) 2012. This article is published with open access at Springerlink.com

\begin{abstract}
We present clinical practice recommendations for the treatment of children with Alport syndrome who are not enrolled in clinical trials. Our goal is to promote early initiation of a standard therapeutic approach that will facilitate assessment of the safety and efficacy of the protocol. The treatment protocol is based on the reduction of proteinuria, intraglomerular pressure, and renal fibrosis via interference with the renin-angiotensin-aldosterone system.
\end{abstract}

Keywords Alport syndrome · Proteinuria · Angiotensinconverting enzyme inhibitor . Angiotensin receptor blocker . Aldosterone inhibitor

C. E. Kashtan $(\bowtie) \cdot$ M. Rheault

Department of Pediatrics, Division of Pediatric Nephrology,

University of Minnesota Medical School,

Minneapolis, MN, USA

e-mail: kasht001@umn.edu

J. Ding

Pediatric Department, Peking University First Hospital,

Beijing, People's Republic of China

\section{Gregory}

Division of Nephrology,

University of Utah Health Sciences Center,

Salt Lake City, UT, USA

\section{Introduction}

Investigation of Alport syndrome (AS) has elucidated the roles of type IV collagen in basement membranes and described the consequences of type IV collagen mutations for renal, cochlear, and ocular structure and function. Research studies employing animal models of AS have suggested interventions that may delay or reverse the renal effects of type IV collagen mutations, but these approaches have yet to be prospectively examined in human subjects with the disease. While we wait for clinical trials to be organized, funded, and carried to completion, children and adults with AS continue to

O. Gross

Department of Nephrology and Rheumatology,

University Medicine Goettingen,

Goettingen, Germany

L. Heidet $\cdot$ B. Knebelmann

Centre de référence pour les Maladies Rénales Héréditaires de l'Enfant et de l'Adulte (MARHEA) and Service de Néphrologie Pédiatrique, Hôpital Necker-Enfants malades,

Paris, France

C. Licht

The Hospital for Sick Children, Division of Nephrology,

Toronto, Canada 
progress towards end-stage renal disease (ESRD). What can nephrologists offer in the meantime, and what can we learn from clinical practice about the efficacy and safety of common treatment approaches?

The Alport Syndrome Research Collaborative, currently comprising investigators in Canada, China, France, Germany, and the United States, has developed clinical practice recommendations aimed at standardizing therapy for people with AS who are not enrolled in clinical trials. It is our hope that adoption of a consistent approach to therapy will allow pooling and analysis of data about treatment responses and efficacy.

\section{Disclaimer}

These are general clinical practice recommendations for offlabel therapy with inhibitors of the renin-angiotensin-aldosterone system (RAAS) and may not be appropriate for all children with AS. It is expected that practitioners will carefully consider a child's baseline renal function in applying these guidelines, will appropriately monitor for adverse effects of therapy, and will adjust or discontinue therapy as needed.

Natural history of untreated Alport syndrome

\section{Genetics and genotype-phenotype correlations}

Alport syndrome can be transmitted as an X-linked, autosomal recessive or autosomal dominant disorder. About 80\% of individuals with AS have X-linked disease (XLAS) due to mutations in the COL4A5 gene. Males with XLAS progress inexorably to ESRD, with ESRD risks of $50 \%$ by age $25,90 \%$ by age 40 , and nearly $100 \%$ by age 60 [1]. Age at ESRD is strongly correlated with COL4A5 genotype in males with XLAS [1-3]; risk of ESRD by age 30 is $90 \%$ for deletions and nonsense mutations of COL $4 A 5,70 \%$ for splicing mutations, and $50 \%$ for missense mutations. The known strong genotype-phenotype correlation provides a rationale for using COL4A5 genotype data to guide the timing and intensity of intervention. In most families with XLAS, age at ESRD is fairly similar among affected males. In the absence of COL $4 A 5$ genotype data, timing of ESRD can be predicted for a young affected male on the basis of ESRD timing in older affected male relatives.

The effects of COL4A5 genotype on age at ESRD are not observed in females with XLAS, likely due to the overwhelming influence of X-inactivation [4]. In XLAS females, the timing and intensity of intervention should be guided by risk factors for progression to ESRD: proteinuria, gross hematuria, and hearing loss $[5,6]$.

Autosomal recessive AS (ARAS) accounts for about $15 \%$ of individuals with the disease and arises from mutations in both alleles of either COL4A3 or COL4A4. Genotypephenotype data for ARAS is relatively sparse. In general, individuals with ARAS carry a high risk of ESRD by age 30 . Only about $5 \%$ of individuals with AS have autosomal dominant disease (ADAS). As ADAS tends to progress at a relatively slow velocity [7], there is less urgency to consider initiation of intervention in childhood.

\section{Clinicopathological correlations}

In general, AS is characterized by genetically determined dysfunction of the glomerular filter, mainly caused by mutations in the collagens assembling the glomerular basement membrane (GBM). In consequence, the earliest sign of GBM filter dysfunction is hematuria followed by albuminuria and subsequent nonselective proteinuria in increasing magnitude. Ultimately, not the GBM damage per se but the pro-inflammatory and pro-fibrotic consequences both in the tubulointerstitium and in the glomeruli resulting from progressive proteinuria, eventually lead to the development of ESRD [8].

Overt proteinuria is typically absent in infant males with XLAS. Age at identification of overt proteinuria shows interfamilial variability and ranges from early childhood to adolescence. In dogs with XLAS, a period of microalbuminuria precedes the development of overt proteinuria and quantitative increases in interstitial volume due to tubular atrophy and fibrosis [9]. Dogs with XLAS exhibit increased proximal tubular epithelial cell uptake of albumin, a process that has been linked to cellular injury [9]. Preliminary data from the Alport Syndrome Treatments and Outcomes Registry (ASTOR) indicates that boys with AS also exhibit a transitional stage of microalbuminuria before overt proteinuria becomes established (manuscript in preparation). It has yet to be demonstrated that suppression of microalbuminuria has antifibrotic effects in AS, although this is a reasonable hypothesis.

Measurements of cortical interstitial volumes in AS males have shown that interstitial fibrosis is unusual before age 10 [10]. Cortical interstitial volumes become abnormal in many AS males during the second decade of life, and are inversely correlated with glomerular filtration rates [10]. These observations suggest that, (1) as in other chronic glomerulopathies, interstitial fibrosis is a significant contributor to loss of renal function, and (2) prevention of interstitial fibrosis in AS males may require intervention during childhood.

\section{Therapeutic studies}

Several therapies improve outcomes in animal models of AS, including angiotensin-converting enzyme (ACE) inhibition [11, 12], AT1-receptor blockade (ARB) [11, 12], inhibitors of TGF- $\beta 1$, matrix metalloproteinases, vasopeptidase A or HMGCoA reductase [13-16]; chemokine receptor 1 blockade [17], 
BMP-7 [18], stem cells [19-22], and irradiation [23]. However, none of these approaches has been prospectively studied in human AS populations.

In ARAS mice, initiation of ACE inhibitor therapy before onset of proteinuria suppressed proteinuria and azotemia and doubled length of survival [11], a therapeutic benefit that has yet to be exceeded by any other intervention. A smaller but still significant improvement in outcome was achieved when ACE inhibition was started after onset of proteinuria [11]. ACE inhibitor therapy begun before onset of proteinuria lengthened survival in canine XLAS [24].

Retrospective analysis of registry data strongly suggests that ACE inhibition delays ESRD and improves life expectancy in AS patients in a time-dependent manner [25]. This observation highlights the importance of early and accurate diagnosis of AS, including specific genotyping whenever feasible (for information on diagnostic methods in AS, please see www.genereviews.org). Besides the beneficial effects of RAAS blockade on outcomes in experimental and human AS, there are additional compelling reasons to recommend RAAS blockade in AS patients until a superior therapy is identified. First, ACE inhibitor therapy at doses that achieve suppression of proteinuria has been used with a high degree of safety in children with chronic kidney disease $[26,27]$. Further, these agents are widely available and relatively inexpensive, making this therapy accessible to AS patients worldwide.

\section{Clinical trials}

We recognize that a randomized clinical trial would be the best way to evaluate the efficacy of ACE inhibition or any other intervention in children with AS. We also recognize that widespread adoption of our recommendations may reduce the pool of children who are eligible for clinical trials of potential therapies for AS. Nevertheless, we encourage eligible subjects and their families to consider participation in clinical trials wherever and whenever possible. For example, by the time this document is published, a clinical trial of ACE inhibition in AS will be recruiting subjects residing in Germany, or willing and able to travel to Germany (contact: studie@alport.de; for information and to download flyer see www.alport.de/EARLY_PRO-TECT). The goal of this trial is to clarify if an early start of therapy (in patients with isolated hematuria or microalbuminuria) delays renal failure even more effectively than later onset of therapy (in proteinuric patients) and above all if therapy at early stages of AS is safe.

For those subjects unable to take part in clinical trials, we believe that valuable efficacy and safety data can be collected if these subjects are treated according to a standardized protocol. Currently, many children with AS are receiving $\mathrm{ACE}$ inhibitor therapy in a non-standardized fashion, and information about treatment responses is not being centrally collected or analyzed. We believe that this represents a wasted opportunity.

\section{Treatment recommendations}

Retrospective registry data strongly suggests that in subjects with AS ACE inhibitor therapy initiated once proteinuria has developed but while glomerular filtration rate is well preserved delays ESRD [25]. Similarly, in mice and dogs with AS, interventions that delay the onset of proteinuria or reduce established proteinuria prolong renal survival [11, 24]. Based on these observations, and on the general consensus that suppression of intraglomerular pressure and proteinuria is an important component of the management of chronic glomerular diseases, treatment of proteinuric AS patients with medications that diminish proteinuria is recommended. Proteinuria in children is defined as urine protein-creatinine ratio persistently greater than $0.2 \mathrm{mg} / \mathrm{mg}$ in children over 2 years of age, or urinary protein excretion greater than $4 \mathrm{mg} / \mathrm{m}^{2} / \mathrm{h}$ in a timed collection [28, 29].

Cortical interstitial volume fraction $(\mathrm{VvI} / \mathrm{C})$ is a measure of interstitial fibrosis and tubular atrophy [30]. There is a strong inverse correlation between $\mathrm{VvI} / \mathrm{C}$ and creatinine clearance in boys with AS [10]. In these boys, $\mathrm{VvI} / \mathrm{C}$ is typically within the normal range during the first decade of life, when creatinine clearance is also normal, but often begins to increase during adolescence concurrent with declining creatinine clearance. We presume that COL4A5 mutations associated with relatively rapid progression to ESRD, such as deletions, nonsense, and splicing mutations, result in earlier onset and more aggressive development of interstitial fibrosis and tubular atrophy. In dogs and mice with AS, the onset of proteinuria precedes measurable increases in interstitial fibrosis. In light of these observations, we recommend that in boys with AS who have deletion, nonsense or splicing mutations, or who have a family history of ESRD before age 30, monitoring of urine protein excretion should begin early in life and that an aggressive approach to initiating and escalating proteinuriasuppressing therapies should be followed.

Based on these principles, we make the following recommendations aimed at preventing renal tubular epithelial cell injury and suppressing fibrogenic processes in the renal interstitium (see Fig. 1):

1. Monitoring for microalbuminuria and proteinuria should be initiated by age 1 year in at risk children, or as soon as a diagnosis of Alport syndrome is established, and repeated at least annually.

2. Affected individuals with overt proteinuria (urine proteincreatinine ratio persistently greater than $0.2 \mathrm{mg} / \mathrm{mg}$, or urinary protein excretion greater than $4 \mathrm{mg} / \mathrm{m}^{2} / \mathrm{h}$ in a timed collection) should receive treatment. 
Fig. 1 Algorithm for identifying children with familial hematuria (Alport syndrome or hematuria with thin glomerular basement membranes) who are candidates for intervention. IHC immunohistochemistry; $E M$ electron microscopy; $G B M$ glomerular basement membrane *Depending upon availability and local practice

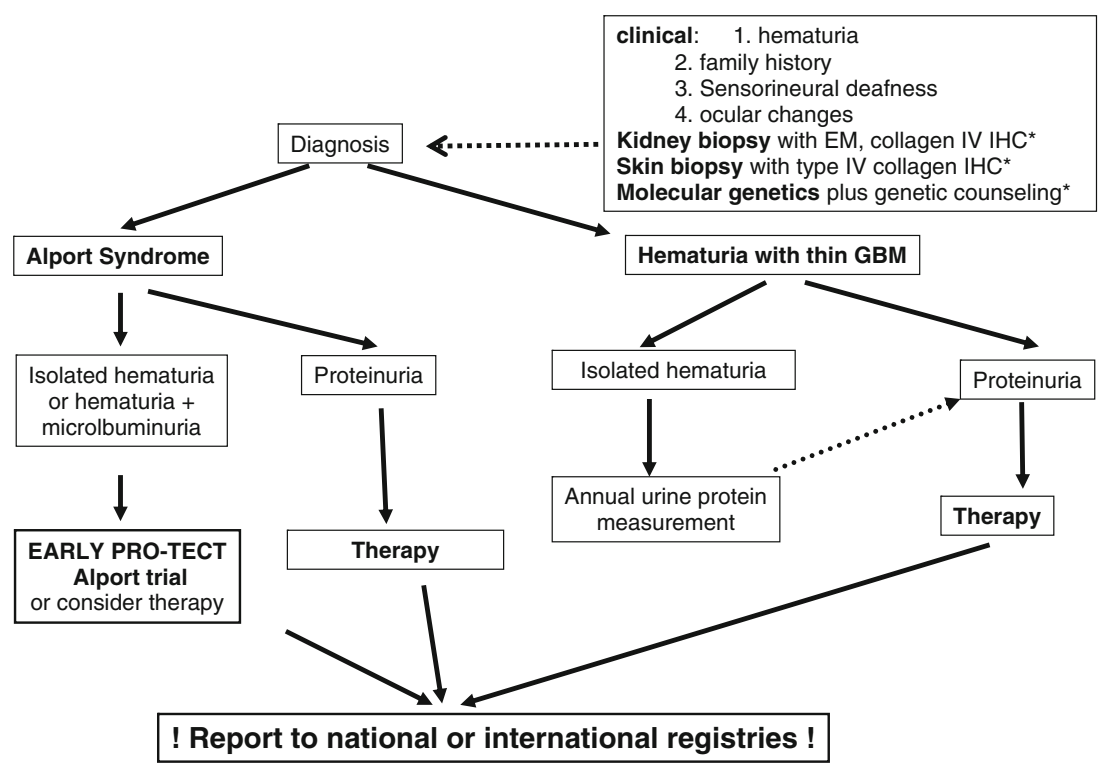

* Depending upon availability and local practice
3. Treatment should be considered in affected boys with microalbuminuria in whom the risk of ESRD by age 30 is high, such as those with COL4A5 deletions, nonsense or splicing mutations, or a history of ESRD before age 30 in affected male relatives (Table 1). We recognize that access to molecular genetic testing for Alport syndrome, and coverage by insurers, is variable. We recommend that the Alport genotype be determined whenever feasible, to facilitate identification of those at high risk of ESRD by age 30 .

\section{Target}

The optimal target for lowering of urine protein levels is uncertain. Our recommendations are based upon an arbitrary goal of a urine protein:creatinine ratio of less than $0.5 \mathrm{mg} / \mathrm{mg}$ if the baseline value is greater than $1.0 \mathrm{mg} / \mathrm{mg}$, or a $50 \%$ reduction if the baseline value is greater than 0.2 but less than 1.0. When therapy is initiated in subjects with microalbuminuria, we recommend a target microalbumin:creatinine ratio of less than 50 $100 \mathrm{mg} / \mathrm{g}$ creatinine.

Proteinuria may persist at levels that exceed these targets, despite maximum dosing of first- and second-line agents. In these cases, we recommend continuing therapy, with adjustment of dosing as indicated by growth and by renal function.

\section{Agents}

First line We chose angiotensin-converting enzyme (ACE) inhibition as first-line therapy for several reasons. First, ACE inhibition is the choice of most nephrologists for initial nonimmunologic therapy of proteinuric glomerular disease. Consequently, practitioners have extensive experience with dosing these agents and are familiar with their adverse effects. ACE inhibitors are widely available and relatively inexpensive. The Evaluation Study of Congestive Heart Failure and Pulmonary

Table 1 Recommendations for intervention based on urinary findings and anticipated disease course

\begin{tabular}{|c|c|c|c|c|}
\hline & \multicolumn{2}{|l|}{$\begin{array}{l}\text { Family history of early ESRD } \\
\text { ( }<30 \text { years) or severe } \\
\text { COL } 4 A 5 \text { mutation }{ }^{\mathrm{a}}\end{array}$} & \multicolumn{2}{|c|}{$\begin{array}{l}\text { Family history of late ESRD } \\
(>30 \text { years) or less severe } \\
\text { COL } 4 A 5 \text { mutation }\end{array}$} \\
\hline & Male & Female & Male & Female \\
\hline Hematuria & $\begin{array}{l}\text { Intervention prior to onset of } \\
\text { microalbuminuria is not } \\
\text { recommended at this time }\end{array}$ & No & No & No \\
\hline Hematuria + microalbuminuria & Consider intervention & Consider intervention & No & No \\
\hline Hematuria + proteinuria & Yes & Yes & Yes & Yes \\
\hline
\end{tabular}

${ }^{\text {a }}$ Deletion, nonsense, or splicing mutation

${ }^{\mathrm{b}}$ Missense mutation

ESRD end stage renal disease 
Artery Catheterization Effectiveness (ESCAPE) trial demonstrated that ACE inhibition with ramipril is associated with very low frequencies of adverse events in children with chronic kidney disease and at least transient reductions in proteinuria $[26,27]$. Because of the ESCAPE experience, we chose ramipril as the reference $\mathrm{ACE}$ inhibitor, and suggest equivalent doses of other ACE inhibitors in Table 2. Finally, ramipril therapy started before or after onset of proteinuria significantly prolonged survival in mice with autosomal recessive Alport syndrome, and its effects were superior to those of candesartan [11, 12].

In the ESCAPE trial, reduction in proteinuria and preservation of glomerular filtration rate were correlated with ramipril's antihypertensive effect [26, 27]. Many of the Alport subjects in whom therapy is initiated when they have developed microalbuminuria or mild proteinuria will be normotensive. If the renoprotective properties of ACE inhibitors are primarily due to their antihypertensive effects, the impact on Alport subjects may be insignificant. However, ramipril delays proteinuria and prolongs survival in normotensive autosomal recessive Alport syndrome mice, indicating that other effects of ACE inhibition are important in this model $[11,12]$.

Second line We propose two alternatives for second-line therapy, angiotensin receptor blockade (ARB) and aldosterone inhibition. For those nephrologists with experience combining an ACE inhibitor with an ARB, ARB may be the more comfortable, familiar approach. We suggest losar$\tan$ as the reference ARB, based on published experience in children with chronic kidney disease [31]. In a recent study of 30 proteinuric children with AS, losartan was found to reduce proteinuria to a greater extent than placebo or amlodipine [32]. We recommend a relatively low starting dose, given that the ARB will be added to ACE inhibition (Table 3). If an ARB is used instead of an ACE inhibitor, for example because a patient tolerates ACE inhibition poorly, a higher starting dose for the ARB would be appropriate.

Table 2 First-line therapy (angiotensin-converting enzyme inhibitor)

\begin{tabular}{ll}
\hline Agent & Dose \\
\hline Ramipril & $\begin{array}{l}\text { Starting dose of } 1 \text { to } 2 \mathrm{mg} / \mathrm{m}^{2} / \text { day; increase } \\
\text { by } 1 \text { to } 2 \mathrm{mg} / \mathrm{m}^{2} / \text { day every } 3 \text { months until } \\
\text { target UPC or adverse effect is attained; } \\
\text { maximum dose } 6 \mathrm{mg} / \mathrm{m}^{2} / \text { day }\end{array}$ \\
$\begin{array}{l}2 \times \text { Ramipril dose }\left(2 \text { to } 4 \mathrm{mg} / \mathrm{m}^{2} / \text { day }\right) \\
\text { Enalapril } \\
\begin{array}{l}\text { Lisinopril } \\
\text { Benazepril }\end{array}\end{array}$ \\
$\begin{array}{l}\text { Fosinopril } \\
\text { Quinapril } \\
\text { Cilazapril } \\
\text { Perinopril }\end{array}$ \\
$\begin{array}{l}\text { Trandolapril } \\
\text { Tramipril dose }\left(4 \text { to } 8 \mathrm{mg} / \mathrm{m}^{2} / \text { day }\right)\end{array}$ \\
\hline
\end{tabular}

Table 3 Second-line therapy (angiotensin receptor blocker)

\begin{tabular}{ll}
\hline Agent & Dose \\
\hline Losartan & $\begin{array}{c}12.5 \mathrm{mg} / \mathrm{m}^{2} / \text { day; double dose every } 3 \text { month } \\
\text { until target UPC or adverse effect is attained; } \\
\text { maximum dose } 50 \mathrm{mg} / \mathrm{m}^{2} / \text { day }\end{array}$ \\
Candesartan & $\begin{array}{l}0.2 \times \text { Losartan dose }\left(6.25 \mathrm{mg} / \mathrm{m}^{2} / \text { day }\right) \\
\text { Irbesartan }\end{array}$ \\
$\begin{array}{l}\text { Telmisartan } \\
\text { Valsartan }\end{array}$ & $\begin{array}{l}0.8 \times \text { Losartan dose }\left(37.5 \mathrm{mg} / \mathrm{m}^{2} / \text { day }\right) \\
\text { Epresartan }\end{array}$ \\
\hline
\end{tabular}

There are a limited number of published reports regarding the use of combination therapy with an ACE inhibitor and an ARB in children with chronic proteinuric renal diseases. Ten children with chronic kidney disease and persistent proteinuria, despite maximal doses of an ACE inhibitor, exhibited a sustained reduction in proteinuria after addition of losartan, with no significant changes in blood pressure or glomerular filtration rate [33]. In another small study of ten children with chronic kidney disease and proteinuria that employed a cross-over design, combination therapy with an ACE inhibitor and an ARB reduced proteinuria to a significantly greater extent than either agent alone [34].

In a small group of patients with AS, combined therapy with an ACE inhibitor and spironolactone suppressed proteinuria to a greater extent than the combination of an ACE inhibitor with an ARB [35]. Hyperkalemia was not encountered in this small group of patients. Increased aldosterone levels (aldosterone escape) may contribute to persistent proteinuria in Alport patients receiving ACE inhibitor therapy [36]. Aldosterone inhibition could be used as the initial second-line agent, or as an alternative to ineffective ARB therapy (Table 4).

\section{Potential adverse effects of therapy}

Potential adverse effects of the therapeutic approach described above include orthostatic hypotension, fetopathy in ovulating females, hyperkalemia, reversible decline in glomerular filtration rate, and gynecomastia. In the ESCAPE trial, only three of 352 children who received ramipril for at least 6 months required discontinuation of therapy because of orthostatic hypotension or hyperkalemia [24]. ACE inhibitors and ARBs should be used with caution in ovulating females in order to avoid fetal injury.

Table 4 Second-line therapy (aldosterone antagonist)

\begin{tabular}{ll}
\hline Agent & Dose \\
\hline Spironolactone & $\begin{array}{l}25 \text { mg daily for subjects 10-20 years of age; } \\
\text { consider lower starting dose in children } \\
\text { less than 10 years of age }\end{array}$ \\
\hline
\end{tabular}


In the ONgoing Telmisartan Alone and in Combination with Ramipril Global Endpoint Trial (ONTARGET) study, the combination of ramipril and telmisartan resulted in increased risk of adverse renal outcomes (doubling of serum creatinine and requirement for dialysis), hypotensive symptoms, syncope, and hyperkalemia, compared to ramipril monotherapy [37]. Subjects who received combination therapy also had an increased risk of mortality, although not statistically significant [37]. The relevance of the results of the ONTARGET study, in which study subjects had a mean age of 66 years and were at high risk for cardiovascular events due to vascular disease or diabetes, to children and young adults with Alport syndrome is unclear.

Chronic administration of spironolactone is associated with an increased incidence of serum potassium greater than $5.5 \mathrm{mEq} / 1$ (about $3 \%$ of subjects participating in clinical trials), gynecomastia (about $5 \%$ of patients), and acute renal insufficiency (1-5\% of subjects) [38]. We recommend regular monitoring of serum potassium and creatinine levels in treated Alport patients, especially those receiving combination therapy.

\section{Reporting of treatment experience}

We are in the process of developing an online reporting tool that will allow practitioners to upload de-identified information regarding treatment responses to a secure site. Once the tool is in place, we will assist interested practitioners in obtaining local IRB approval for participation. We will use listservs and blast e-mails from the Alport Syndrome Treatments and Outcomes Registry to announce the availability of the site. In the meantime, we encourage practitioners to share treatment experiences via e-mail with Dr. Kashtan.

Acknowledgements The Alport Syndrome Treatments and Outcomes Registry (C.K., M.G., M.R., C.L.) receives support from private donors and the Alport Syndrome Foundation (www.alportsyndrome.org). The European Alport Registry is supported by the Association pour l'Information et la Recherche sur les Maladies Rénales Génétiques (AIRG) (to O.G.) and the KfH Foundation Preventive Medicine (Fritz-Scheler Stipendium of the German Society of Nephrology) (to O.G.). The EARLY PRO-TECT Alport trial is funded by the German Ministry of Education and Research (O.G.).

Open Access This article is distributed under the terms of the Creative Commons Attribution License which permits any use, distribution, and reproduction in any medium, provided the original author(s) and the source are credited.

\section{References}

1. Jais JP, Knebelmann B, Giatras I, De Marchi M, Rizzoni G, Renieri A, Weber M, Gross O, Netzer K-O, Flinter F, Pirson Y, Verellen C, Wieslander J, Persson U, Tryggvason K, Martin P, Hertz JM, Schroder C, Sanak M, Krejcova S, Carvalho MF, Saus J, Antignac C, Smeets H, Gubler MC (2000) X-linked Alport syndrome: natural history in 195 families and genotype-phenotype correlations in males. J Am Soc Nephrol 11:649-657
2. Gross O, Netzer KO, Lambrecht R, Seibold S, Weber M (2002) Meta-analysis of genotype-phenotype correlation in X-linked Alport syndrome: impact on clinical counseling. Nephrol Dial Transpl 17:1218-1227

3. Bekheirnia MR, Reed B, Gregory MC, McFann K, Shamshirsaz AA, Masoumi A, Schrier RW (2010) Genotype-phenotype correlation in X-linked Alport syndrome. J Am Soc Nephrol 21:876-883

4. Rheault MN, Kren SM, Hartich LA, Wall M, Thomas W, Mesa HA, Avner P, Lees GE, Kashtan CE, Segal Y (2010) Xinactivation modifies disease severity in female carriers of murine X-linked Alport syndrome. Nephrol Dial Transplant 25:764-769

5. Grunfeld J-P, Noel LH, Hafez S, Droz D (1985) Renal prognosis in women with hereditary nephritis. Clin Nephrol 23:267-271

6. Jais JP, Knebelmann B, Giatras I, De Marchi M, Rizzoni G, Renieri A, Weber M, Gross O, Netzer KO, Flinter F, Pirson Y, Dahan K, Wieslander J, Persson U, Tryggvason K, Martin P, Hertz JM, Schroder C, Sanak M, Carvalho MF, Saus J, Antignac C, Smeets H, Gubler MC (2003) X-linked Alport syndrome: natural history and genotype-phenotype correlations in girls and women belonging to 195 families: a "European Community Alport Syndrome Concerted Action" study. J Am Soc Nephrol 14:2603-2610

7. Pochet JM, Bobrie G, Landais P, Goldfarb B, Grunfeld J-P (1989) Renal prognosis in Alport's and related syndromes: influence of the mode of inheritance. Nephrol Dial Transpl 4:1016-1021

8. Gross O, Kashtan CE (2009) Treatment of Alport syndrome: beyond animal models. Kidney Int 76:599-603

9. Vinge L, Lees GE, Nielsen R, Kashtan CE, Bahr A, Christensen EI (2010) The effect of progressive glomerular disease on megalinmediated endocytosis in the kidney. Nephrol Dial Transplant 25:2458-2467

10. Kashtan CE, Gubler MC, Sisson-Ross S, Mauer M (1998) Chronology of renal scarring in males with Alport syndrome. Pediatr Nephrol 12:269-274

11. Gross O, Beirowski B, Koepke ML, Kuck J, Reiner M, Addicks K, Smyth N, Schulze-Lohoff E, Weber M (2003) Preemptive ramipril therapy delays renal failure and reduces renal fibrosis in COL4A3knockout mice with Alport syndrome. Kidney Int 63:438-446

12. Gross O, Schulze-Lohoff E, Koepke ML, Beirowski B, Addicks K, Bloch W, Smyth N, Weber M (2004) Antifibrotic, nephroprotective potential of ACE inhibitor vs AT1 antagonist in a murine model of renal fibrosis. Nephrol Dial Transplant 19:1716-1723

13. Sayers R, Kalluri R, Rodgers KD, Shield CF, Meehan DT, Cosgrove D (1999) Role for transforming growth factor-beta 1 in Alport renal disease progression. Kidney Int 56:1662-1673

14. Gross O, Koepke ML, Beirowski B, Schulze-Lohoff E, Segerer S, Weber M (2005) Nephroprotection by antifibrotic and antiinflammatory effects of the vasopeptidase inhibitor AVE7688. Kidney Int 68:456-463

15. Zeisberg M, Khurana M, Rao VH, Cosgrove D, Rougier JP, Werner MC, Shield CF, Werb Z, Kalluri R (2006) Stage-specific action of matrix metalloproteinases influences progressive hereditary kidney disease. PLoS Med 3:e100

16. Koepke ML, Weber M, Schulze-Lohoff E, Beirowski B, Segerer S, Gross O (2007) Nephroprotective effect of the HMG-CoA-reductase inhibitor cerivastatin in a mouse model of progressive renal fibrosis in Alport syndrome. Nephrol Dial Transplant 22:1062-1069

17. Ninichuk V, Gross O, Reichel C, Kandoga A, Pawar RD, Ciubar R, Segerer S, Belemezova E, Radomska E, Luckow B, Perez de Lema G, Murphy PM, Gao J, Henger A, Kretzler M, Horuk R, Weber M, Krombach F, Schlondorff D, Anders H (2005) Delayed chemokine receptor 1 blockade prolongs survival in collagen 4A3-deficient mice with Alport disease. J Am Soc Nephrol 16:977-985

18. Zeisberg M, Bottiglio C, Kumar N, Maeshima Y, Strutz F, Muller GA, Kalluri R (2003) Bone morphogenic protein-7 inhibits progression of chronic renal fibrosis associated with two genetic mouse models. Am J Physiol Renal Physiol 285:F1060-F1067 
19. Ninichuk V, Gross O, Segerer S, Hoffmann R, Radomska E, Buchstaller A, Huss R, Akis N, Schlondorff D, Anders HJ (2006) Multipotent mesenchymal stem cells reduce interstitial fibrosis but do not delay progression of chronic kidney disease in collagen4A3-deficient mice. Kidney Int 70:121-129

20. Sugimoto H, Mundel TM, Sund M, Xie L, Cosgrove D, Kalluri R (2006) Bone-marrow-derived stem cells repair basement membrane collagen defects and reverse genetic kidney disease. Proc Natl Acad Sci USA 103:7321-7326

21. Gross O, Borza DB, Anders HJ, Licht C, Weber M, Segerer S, Torra R, Gubler MC, Heidet L, Harvey S, Cosgrove D, Lees G, Kashtan C, Gregory M, Savige J, Ding J, Thorner P, Abrahamson DR, Antignac C, Tryggvason K, Hudson B, Miner JH (2009) Stem cell therapy for Alport syndrome: the hope beyond the hype. Nephrol Dial Transplant 24:731-734

22. Lebleu V, Sugimoto H, Mundel TM, Gerami-Naini B, Finan E, Miller CA, Gattone VH, Lu L, Shield CF, Folkman J, Kalluri R (2009) Stem cell therapies benefit Alport syndrome. J Am Soc Nephrol 20:2359-2370

23. Katayama K, Kawano M, Naito I, Ishikawa H, Sado Y, Asakawa $\mathrm{N}$, Murata T, Oosugi K, Kiyohara M, Ishikawa E, Ito M, Nomura S (2008) Irradiation prolongs survival of Alport mice. J Am Soc Nephrol 19:1692-1700

24. Grodecki KM, Gains MJ, Baumal R, Osmond DH, Cotter B, Valli VE, Jacobs RM (1997) Treatment of X-linked hereditary nephritis in Samoyed dogs with angiotensin-converting enzyme inhibitor. J Comp Pathol 117:209-225

25. Gross O, Licht C, Anders H, Hoppe B, Beck B, Tonshoff B, Hocker B, Wygoda S, Ehrich J, Pape L, Konrad M, Rascher W, Dotsch J, Muller-Wiefel D, Hoyer P, Knebelmann B, Pirson Y, Grunfeld J, Niaudet P, Cochat P, Heidet L, Lebbah S, Torra R, Friede T, Lange K, Muller GA, Weber M (2012) Early angiotensin-converting enzyme inhibition in Alport syndrome delays renal failure and improves life expectancy. Kidney Int. doi:10.1038/ki.2011.407

26. Wuhl E, Mehls O, Schaefer F (2004) Antihypertensive and antiproteinuric efficacy of ramipril in children with chronic renal failure. Kidney Int 66:768-776

27. Wuhl E, Trivelli A, Picca S, Litwin M, Peco-Antic A, Zurowska A, Testa S, Jankauskiene A, Emre S, Caldas-Afonso A, Anarat A, Niaudet P, Mir S, Bakkaloglu A, Enke B, Montini G, Wingen AM, Sallay P, Jeck N, Berg U, Caliskan S, Wygoda S, HohbachHohenfellner K, Dusek J, Urasinski T, Arbeiter K, Neuhaus T, Gellermann J, Drozdz D, Fischbach M, Moller K, Wigger M, Peruzzi
L, Mehls O, Schaefer F (2009) Strict blood-pressure control and progression of renal failure in children. N Engl J Med 361:1639-1650

28. Elises JS, Griffiths PD, Hocking MD, Taylor CM, White RH (1998) Simplified quantification of urinary protein excretion in children. Clin Nephrol 30:225-229

29. Hogg RJ, Portman RJ, Milliner D, Lemley KV, Eddy A, Ingelfinger $J$ (2000) Evaluation and management of proteinuria and nephrotic syndrome in children: recommendations from a pediatric nephrology panel established at the National Kidney Foundation Conference on Proteinuria, Albuminuria, Risk, Assessment, and Elimination (PARADE). Pediatrics 105:12421249

30. Lane PH, Steffes MW, Fioretto P, Mauer SM (1993) Renal interstitial expansion in insulin-dependent diabetes mellitus. Kidney Int 43:661-667

31. Ellis D, Moritz M, Vats A, Janosky JE (2004) Antihypertensive and renoprotective efficacy and safety of losartan. Am J Hypertens 17:928-935

32. Webb NJ, Lam C, Shahinfar S, Strehlau J, Wells TG, Gleim GW, Le Bailly De Tilleghem C (2011) Efficacy and safety of losartan in children with Alport syndrome - results from a subgroup analysis of a prospective, randomized placebo- or amlodipine-controlled trial. Nephrol Dial Transplant 28:2521-2526

33. Seeman T, Pohl M, Misselwitz J, John U (2009) Angiotensin receptor blocker reduces proteinuria independently of blood pressure in children already treated with angiotensin-converting enzyme inhibitors. Kidney Blood Press Res 32:440-444

34. Lubrano R, Soscia F, Elli M, Ventriglia F, Raggi C, Travasso E, Scateni S, Di Maio V, Versacci P, Masciangelo R, Romero S (2006) Renal and cardiovascular effects of angiotensinconverting enzyme inhibitor plus angiotensin II receptor antagonist therapy in children with proteinuria. Pediatrics 118:e833-e838

35. Kaito H, Nozu K, Iijima K, Nakanishi K, Yoshiya K, Kanda K, Przybyslaw Krol R, Yoshikawa N, Matsuo M (2006) The effect of aldosterone blockade in patients with Alport syndrome. Pediatr Nephrol 21:1824-1829

36. Ku E, Campese VM (2009) Role of aldosterone in the progression of chronic kidney disease and potential use of aldosterone blockade in children. Pediatr Nephrol 24:2301-2307

37. The ONTARGET Investigators (2008) Telmisartan, ramipril, or both in patients at high risk for vascular events. N Eng J Med $358: 1547-1559$

38. Marrs JC (2010) Spironolactone management of resistant hypertension. Ann Pharmacother 44:1762-1769 